\title{
Feeding Patterns and Predictors of Malnutrition in Infants from Poor Socioeconomic Areas in Pakistan: A Cross- sectional Survey
}

Muhammad Umer Nisar ${ }^{1}$, Malik Muhammad Anwar ul Haq ${ }^{2}$, Saad Tariq ${ }^{3}$, Madiha Anwar 4 Anam Khawar ${ }^{2}$, Ahmed Waqas ${ }^{5}$, Anam Nisar ${ }^{6}$

1. Medical Student, Yusra Medical and Dental College, Islamabad, Pakistan 2. District Headquarter Hospital, Sargodha, Pakistan 3. Dow Medical College, Karachi, Pakistan 4. Combined Military Hospital, Mangla, Pakistan 5. Department of Psychiatry, CMH Lahore Medical College and Institute of Dentistry 6. POF Hospital, Wah Cantt, Pakistan

$\square$ Corresponding author: Muhammad Umer Nisar, umar8000@hotmail.com Disclosures can be found in Additional Information at the end of the article

\section{Abstract}

Introduction: Malnutrition, a state of under or over nutrition caused by improper food intake, causes significant morbidity and mortality in developing countries. It leads to a number of diseases which can be further divided into those caused by protein-caloric malnutrition and those caused by vitamin deficiencies, micronutrient, and mineral deficiencies. The purpose of this study was to identify the factors which contribute to malnutrition and to assess the dietary pattern in the pediatric population from birth up to five months belonging to poor socioeconomic areas. The children in this sample presented to a tertiary care hospital in the district of Sargodha, Pakistan. The findings in this cohort will support the development of an effective plan to tackle these issues.

Methods: This cross-sectional study was undertaken between June 2014 and December 2014 at the inpatient pediatric department of District Headquarter Hospital Sargodha. Data were collected and recorded on a predesigned form which consisted of four sections to record 1) demographics: parents' level of education, monthly income, number of dependent household members, and birth interval; 2) anthropometric and personal history, birth history, and degree of malnutrition; 3) any secondary causes of malnutrition; and 4) feeding history. The data were analyzed in SPSS v. 20. Chi-squared, phi statistics, and logistic regression analysis were run to analyze the data.

Received 10/28/2015 Review began 10/29/2015 Review ended 12/18/2015 Published 01/07/2016

C) Copyright 2016

Nisar et al. This is an open access article distributed under the terms of the Creative Commons Attribution License CC-BY 3.0., which permits unrestricted use, distribution, and reproduction in any medium, provided the original author and source are credited.
Results: A total of 294 participants were included in the study. Logistic regression analysis showed that the degree of malnutrition was associated negatively with increasing age and positively with family size. A majority of children (144, 49\%) were being breastfed for less than 5 minutes followed by $38(13 \%)>5$ minutes to 15 minutes, and $2(0.7 \%)>15$ minutes while 110 (37\%) infants were not breastfed. Children who were breastfed were less likely to have severe malnutrition than those who were given formula, fresh cow's or goat's milk, or more than one type of food.

Conclusion: Children who were breastfed were less likely to have severe malnutrition. The degree of malnutrition was negatively associated with age and positively associated with family size.

How to cite this article

Nisar M, Anwar ul haq M, Tariq S, et al. (January 07, 2016) Feeding Patterns and Predictors of Malnutrition in Infants from Poor Socioeconomic Areas in Pakistan: A Cross-sectional Survey. Cureus 8(1): e452. DOI 10.7759/cureus.452 
Categories: Pediatrics, Public Health, Epidemiology/Public Health

Keywords: malnutrition, children, breast feeding, nutrition

\section{Introduction}

South Asian countries have the highest burden of malnourished children under five years of age [1-3]. Half of the children in South Asia are malnourished, and half of world's malnourished children live in Pakistan, Bangladesh, and India [3-4]. Malnutrition has multifactorial effects on physical, social, mental, and intellectual development, which highlights the importance of proper nutrition in children [5].

Pakistan has the highest child and infant mortality rate in South Asia [6]. The mortality in children under five years of age was 101 per 1000 live births, as reported in 2005, with malnutrition being a major contributor [4, 7]. A national survey in Pakistan showed that onethird of the children are malnourished, 6.2-8.3 million children (about 30\%-40\%) have low height for their age (stunting), and more than 2.9 million children (14\%) have low weight for their height (wasting) [8]. Another national survey in this country also showed that during the decade from 1990 to 2001, the proportion of underweight children under five years of age had decreased slightly from $40.1 \%$ to $37.4 \%$; however, the prevalence of wasting had increased from $11.8 \%$ to $14.9 \%$, and the prevalence of stunting had increased from $36.3 \%$ to $40 \%$ [4]. This indicates that malnutrition is a developing problem for children in Pakistan - an issue that poses a threat to the achievement of the United Nations Millennium Development Goal number 4 , i.e. to reduce child mortality by 2015 . To highlight the seriousness of this issue, this report presents the key determinants of malnutrition among young Pakistani children.

The present study was designed to determine the feeding patterns and predictors of malnutrition in children from birth up to five months of age in Pakistan.

\section{Materials And Methods}

This cross-sectional study was undertaken between June 2014 and December 2014 in the District Headquarter Hospital (DHQ) Sargodha, Pakistan. Ethical approval was obtained from the Ethical Review Committee of Yusra Medical and Dental College, Islamabad. Two hundred and ninety-four children under five months of age followed at the inpatient department of DHQ Sargodha were included in the study. The minimum sample size required for the survey was calculated to be 384 based on a $95 \%$ confidence level, $5 \%$ margin of error, and a population of 11.2 million children suffering from malnutrition in Pakistan [8-9]. However, due to limited resources, we could not achieve the required sample size. Therefore, the results from this study are not generalizable to the Pakistani populace.

Written consent was obtained from all participants following a comprehensive explanation of the purposes of the study. Children with serious illness or comorbidities were excluded from the study. Detailed history and anthropometric measurements were taken by a physician.

Data were collected and recorded on a pretested, predesigned form which consisted of four sections. The first section recorded demographics, parents' level of education, monthly income, the number of dependent household members, and birth interval. The second section recorded anthropometric data and personal history, birth history, and degree of malnutrition. The degree of malnutrition were categorized as first degree (75-90\% of expected weight), second degree (60-75\% of expected weight), and third degree (<60\% of expected weight). The third section recorded any secondary cause(s) of malnutrition. The fourth section recorded feeding history, including details about breastfeeding, formula feeding, and fresh cow's or goat's milk feeding. 


\section{Cureus}

The data were analyzed in SPSS v. 21 (IBM, Chicago, Illinois). Frequencies, percentages, and the chi-squared goodness of fit test were run for participants' characteristics and feeding patterns. Logistic regression analysis was used to elucidate the predictors of severity of malnutrition in the infants. Covariates entered into the logistic regression model were the age of the infant, gender, mother's education, income, family size, background, gestation, mode of delivery, and type of feeding. The degree of malnutrition was dichotomized as "first degree" and "severe" (second, plus third-degree malnutrition) and entered as a dependent variable.

\section{Results}

The mean age of the infants was 3.51 months and the mean number of family members was 7.14. Most of the infants included in the survey were males, had illiterate mothers, had family income < Rs. 20,000/month (200 USD) and belonged to rural areas. Most of the respondents had SVD and partial immunization status. Almost $45 \%$ of the infants were being breastfed. Detailed results are given in Table 1 .

\begin{tabular}{|c|c|c|c|c|}
\hline \multicolumn{2}{|l|}{ Characteristics } & $\begin{array}{l}\text { Frequency } \\
\text { (n) }\end{array}$ & $\begin{array}{l}\text { Percentage } \\
\text { (\%) }\end{array}$ & $\begin{array}{l}\text { Chi Square P- } \\
\text { value }\end{array}$ \\
\hline \multirow{2}{*}{ Gender } & Male & 173 & $58.80 \%$ & $<.001$ \\
\hline & Female & 121 & $42.20 \%$ & \\
\hline \multirow{4}{*}{ Mothers' Education } & Cannot read and write & 195 & $66.30 \%$ & $<.001$ \\
\hline & Primary School & 41 & $13.90 \%$ & \\
\hline & Secondary School & 49 & $16.70 \%$ & \\
\hline & Higher Secondary School & 9 & $3 \%$ & \\
\hline \multirow{3}{*}{$\begin{array}{l}\text { Monthly Income } \\
\text { (combined) }\end{array}$} & $<95$ USD & 101 & $34.50 \%$ & $<.001$ \\
\hline & 95-190 USD & 181 & $61.80 \%$ & \\
\hline & > 190 USD & 11 & $3.80 \%$ & \\
\hline \multirow{2}{*}{ Background } & Urban & 117 & $39.80 \%$ & $<.001$ \\
\hline & Rural & 177 & $60.20 \%$ & \\
\hline \multirow{2}{*}{ Gestation } & Term & 290 & $98.60 \%$ & $<.001$ \\
\hline & Preterm & 4 & $1.40 \%$ & \\
\hline \multirow{5}{*}{ Feeding } & Mother feed & 132 & $44.90 \%$ & $<.001$ \\
\hline & Formula feed & 36 & $12.20 \%$ & \\
\hline & Fresh feed & 74 & $25.20 \%$ & \\
\hline & More than one type & 52 & $17.70 \%$ & \\
\hline & SVD & 217 & $73.80 \%$ & \\
\hline Mode of Delivery & $\begin{array}{l}\text { forceps/vacuum/episiotomy } \\
\text { fith }\end{array}$ & 17 & $5.80 \%$ & $<.001$ \\
\hline
\end{tabular}




\section{Cureus}

\begin{tabular}{|lllll|} 
& Cesarean section & 60 & $20.40 \%$ & \\
& Up to date & 115 & $39.10 \%$ & $<.001$ \\
Immunization Status & partial & 121 & $41.20 \%$ & \\
& none & 58 & $19.70 \%$ & \\
Degree of Malnutrition & 1st Degree & 70 & $23.80 \%$ & $32.70 \%$ \\
& 2nd Degree & 96 & $43.50 \%$ & \\
\hline & 3rd Degree & 128 &
\end{tabular}

TABLE 1: Characteristics of the Children Surveyed $(n=294)$

Table 2 presents the feeding patterns of the infants feeding on mothers' breast milk. Only 184 (62.59\%) infants were receiving mother's milk either alone or combined with other food. Most of the infants were being fed mother's milk $<5$ times/day, 2 times/ night and for $<5$ minutes duration/session. Most commonly cited reason for not breastfeeding was personal preference of the mother and nonavailability/less amount despite spontaneous vaginal delivery (SVD). 


\section{Cureus}

\begin{tabular}{|c|c|c|c|c|}
\hline \multicolumn{2}{|l|}{ Variable } & $\begin{array}{l}\text { Frequency } \\
\text { (n) }\end{array}$ & $\begin{array}{l}\text { Percentage } \\
\text { (\%) }\end{array}$ & $\begin{array}{l}\text { Chi Square P- } \\
\text { value }\end{array}$ \\
\hline \multirow{3}{*}{$\begin{array}{l}\text { No. of Mother Feeds } \\
\text { Given/Day }\end{array}$} & $<5$ & 148 & $80.4 \%$ & $<.001$ \\
\hline & 5 to 10 & 36 & $19.6 \%$ & \\
\hline & $>10$ & 0 & $0.0 \%$ & \\
\hline \multirow{5}{*}{$\begin{array}{l}\text { No. of Mother Feeds } \\
\text { Given/Night }\end{array}$} & 0 & 8 & $4.4 \%$ & $<.001$ \\
\hline & 1 & 67 & $36.4 \%$ & \\
\hline & 2 & 93 & $50.5 \%$ & \\
\hline & 3 & 13 & $7.1 \%$ & \\
\hline & 4 & 3 & $1.6 \%$ & \\
\hline \multirow{3}{*}{ Duration/Feed of Mothers } & $<5 \min$ & 144 & $78.3 \%$ & $<.001$ \\
\hline & $5-15 \min$ & 38 & $20.7 \%$ & \\
\hline & $>15 \min$ & 2 & $1.0 \%$ & \\
\hline \multirow{10}{*}{ Reason of No Mother Feed } & Mother on drugs & 0 & $0.0 \%$ & $<.001$ \\
\hline & Twin, triplets or quadruplets & 5 & $2.7 \%$ & \\
\hline & $\begin{array}{l}\text { Mothers' Illness (organic or } \\
\text { psychiatric) }\end{array}$ & 8 & $4.4 \%$ & \\
\hline & Hot/cold food concept & 1 & $0.5 \%$ & \\
\hline & Mothers' feed not good for baby & 5 & $2.7 \%$ & \\
\hline & Mother is malnourished & 3 & $1.6 \%$ & \\
\hline & Due to C-Section & 13 & $7.1 \%$ & \\
\hline & Personal preference & 57 & $31.0 \%$ & \\
\hline & $\begin{array}{l}\text { Non-availability/less amount } \\
\text { despite SVD }\end{array}$ & 34 & $18.5 \%$ & \\
\hline & No response & 58 & $31.5 \%$ & \\
\hline
\end{tabular}

\section{TABLE 2: Breast feeding patterns in malnourished infants $\left(n=184^{*}\right)$}

* Includes infants in "more than one type of food" category taking breast milk along with other food type.

Less than $40 \%$ of the infants were receiving fresh food. Most of them were receiving cow's milk, $<5$ times/day and 2 times/night. Most of the infants (104/109) received diluted fresh food and the most cited reason for over-dilution was family pressures/financial constraints. Table 3 


\section{Cureus}

details the feeding patterns of infants feeding on fresh food.

\begin{tabular}{|c|c|c|c|c|}
\hline \multicolumn{2}{|l|}{ Variable } & $\begin{array}{l}\text { Frequency } \\
\text { (n) }\end{array}$ & $\begin{array}{l}\text { Percentage } \\
\text { (\%) }\end{array}$ & $\begin{array}{l}\text { Chi Square P- } \\
\text { value }\end{array}$ \\
\hline \multirow{2}{*}{ Type of Fresh Feed } & Cows' milk & 107 & $98.2 \%$ & $<.001$ \\
\hline & any other & 2 & $1.8 \%$ & \\
\hline \multirow{3}{*}{ No. of Fresh Feeds Given/Day } & $<5$ & 100 & $91.7 \%$ & $<.001$ \\
\hline & 5 to 10 & 9 & $8.3 \%$ & \\
\hline & $>10$ & 0 & $0.0 \%$ & \\
\hline \multirow{4}{*}{$\begin{array}{l}\text { No. of Fresh Feeds } \\
\text { Given/Night }{ }^{1}\end{array}$} & 0 & 5 & $4.6 \%$ & $<.001$ \\
\hline & 1 & 31 & $33.9 \%$ & \\
\hline & 2 & 51 & $46.8 \%$ & \\
\hline & 3 & 15 & $13.8 \%$ & \\
\hline \multirow{4}{*}{$\begin{array}{l}\text { Fresh Feed Over-dilution } \\
\text { Reason }^{1}\end{array}$} & No awareness & 24 & $22.0 \%$ & $<.001$ \\
\hline & $\begin{array}{l}\text { Perceived intolerance to undiluted } \\
\text { milk }\end{array}$ & 8 & $7.3 \%$ & \\
\hline & $\begin{array}{l}\text { Family pressures/financial } \\
\text { constraints }\end{array}$ & 67 & $61.2 \%$ & \\
\hline & No over-dilution & 5 & $4.6 \%$ & \\
\hline
\end{tabular}

\section{TABLE 3: Pattern of Feeding of Fresh Food to the Infant ( $\left.n=109^{*}\right)$}

* Includes infants in "more than one type of feed" category taking fresh feed along with other food type.

${ }^{1}$ Contains one to five missing values

Many of the infants $(56,19 \%)$ were receiving formula food, $<5$ times/day and 2 times/night. Nine (9/56) infants were receiving over-diluted food and the most commonly cited reason for over-dilution was no awareness and family pressures/financial constraints. Table 4 details the feeding patterns of infants feeding on formula food. 


\section{Cureus}

\begin{tabular}{|c|c|c|c|c|}
\hline \multicolumn{2}{|l|}{ Variable } & $\begin{array}{l}\text { Frequency } \\
\text { (n) }\end{array}$ & $\begin{array}{l}\text { Percentage } \\
\text { (\%) }\end{array}$ & $\begin{array}{l}\text { Chi square } P \text { - } \\
\text { value }\end{array}$ \\
\hline \multirow{3}{*}{$\begin{array}{l}\text { No. of Formula Feeds } \\
\text { Given/Day }\end{array}$} & $<5$ & 47 & $83.9 \%$ & $<.001$ \\
\hline & 5 to 10 & 9 & $16.1 \%$ & \\
\hline & $>10$ & 0 & $0.0 \%$ & \\
\hline \multirow{4}{*}{$\begin{array}{l}\text { No. of Formula Feeds } \\
\text { Given/Night }\end{array}$} & 0 & 2 & $3.6 \%$ & $<.001$ \\
\hline & 1 & 19 & $33.9 \%$ & \\
\hline & 2 & 30 & $53.6 \%$ & \\
\hline & 3 & 5 & $8.9 \%$ & \\
\hline \multirow{3}{*}{ Dilution/Feed of Formula } & 1 spoon/ounce & 41 & $73.2 \%$ & $<.001$ \\
\hline & $1 / 2$ spoon/ounce & 9 & $16.1 \%$ & \\
\hline & 1/3 spoon/ounce & 6 & $10.7 \%$ & \\
\hline \multirow{4}{*}{$\begin{array}{l}\text { Formula Feed Over-dilution } \\
\text { Reason }\end{array}$} & No awareness & 9 & $16.1 \%$ & $<.001$ \\
\hline & $\begin{array}{l}\text { Perceived intolerance to } \\
\text { undiluted milk }\end{array}$ & 0 & $0.0 \%$ & \\
\hline & $\begin{array}{l}\text { Family pressures/financial } \\
\text { constraints }\end{array}$ & 5 & $8.9 \%$ & \\
\hline & No over-dilution & 42 & $75.0 \%$ & \\
\hline
\end{tabular}

\section{TABLE 4: Pattern of Formula Feed of the Infants Surveyed $\left(n=56^{*}\right)$}

* Includes infants in "more than one type of feed" category taking fresh feed along with other food type.

According to logistic regression analysis, the degree of malnutrition was negatively associated with increasing age and positively with family size. Children who were taking mother's food were less likely to have severe malnutrition than those who were having formula food, fresh food, or more than one type of food. 


\section{Cureus}

\begin{tabular}{|c|c|c|c|c|}
\hline \multirow{2}{*}{ Variables } & \multirow{2}{*}{ Odds Ratio } & \multirow{2}{*}{ P-value } & \multicolumn{2}{|c|}{ 95\% C.I.for Odds Ratio } \\
\hline & & & Lower & Upper \\
\hline Age & 0.505 & 0 & 0.392 & 0.65 \\
\hline Family size & 1.123 & 0.039 & 1.006 & 1.253 \\
\hline More than one feed & & 0.004 & & \\
\hline Mother feed & 0.197 & 0.002 & 0.07 & 0.558 \\
\hline Formula feed & 0.515 & 0.352 & 0.128 & 2.08 \\
\hline Fresh feed & 0.462 & 0.173 & 0.152 & 1.402 \\
\hline Constant & 60.923 & 0 & & \\
\hline
\end{tabular}

TABLE 5: Logistic Regression Analysis (Backwards Method) for Degree of Malnutrition in Children Presenting at the Hospital $(n=294)$

Model Chi square $=59.9, \mathrm{P}<.001$, Hosmer and Lemeshow, $\mathrm{P}=.95$

Cox and Snell $\mathrm{R}$ square $=.17$, Negelkerke $\mathrm{R}$ Square $=.26$

\section{Discussion}

Malnutrition in children is a serious health hazard in a developing country like Pakistan. We searched for factors that contribute to malnutrition in children under five months of age from families with poor socioeconomic status. Our analysis showed that malnutrition was negatively associated with increasing age and positively associated with family size. We also found that children who were breastfed were less likely to have severe malnutrition.

Among the factors associated with malnutrition are the parents' education, income, family size, the birth interval with the older sibling, and feeding pattern. Many studies have shown a significant association between malnutrition and the parents' education, especially the mother's. Ali, et al. reported a significant difference in malnutrition (as shown by low weight) between children whose mothers were illiterate compared to educated mothers in Karachi $(\mathrm{P}<$ 0.016) [10]. Islam, et al. showed that maternal illiteracy and lack of breastfeeding were associated with a four-fold increase in the risk of severe malnutrition in children [11]. Smith, et al., in their study of 63 developing countries for 25 years, concluded that the mother's secondary school enrollment had a strong negative association with child malnutrition, once again highlighting the importance of maternal education [12]. Paternal education also has an impact on child malnutrition because the father is usually the sole earner and decision maker in the family in developing countries, such as Pakistan. Jesmin, et al. showed that a one-year increase in the father's schooling was associated with an $11 \%$ reduction in stunting [13]. A study by Rayhan, et al. showed that the prevalence of underweight was lower in children whose fathers had a higher level of education [14]. Memon, et al. showed that feeding practices are mostly affected by the mother's education $(\mathrm{P}<0.0001)$ and income $(\mathrm{P}<0.0003)[15]$.

Family income is also important for child nutrition. Less income is associated with inadequate 
nutrition, poor sanitation, and an increased risk of infection, which leads to stunting in children [16-18]. Kavosi, et al. showed that stunting was significantly associated with lower family income (OR 3.21, CI: 1.17 - 8.85), and children in families with an income higher than 667 US dollars were less likely to be stunted compared to those with an income of 334 US dollars or less [19]. In the present study, however, we found no significant association between the parents' education or income and malnutrition.

Family size is also an important factor in malnutrition. A study done in India showed that the overall prevalence of protein-energy malnutrition was significantly higher $(\mathrm{P}<0.001)$ in infants from joint families than those from nuclear families. In large families, $74.6 \%$ of children had malnutrition vs. only $21.96 \%$ in small families [20]. Our study also showed that family size was positively associated with malnutrition, according to the logistic regression analysis.

Regarding birth interval, a study of 1,884 children showed that children who had less than a 24month birth interval with the older sibling had increased the risk of malnutrition - a result that points toward the potential benefits of longer birth intervals [21].

Breastfeeding is a cost-effective mechanism to reduce malnutrition in developing countries. The World Health Organization recommends that exclusive breastfeeding should be started soon after birth and continued for six months, followed by the addition of complementary food up to two years of age [22]. A previous study in Pakistan showed that about $27.2 \%$ of infants (95\% CI: 26.0, 28.3) started breastfeeding within one hour of birth and 65.5\% (95\% CI: 64.3, 66.8) within one day [23]. A study in Nepal showed that about $7.7 \%$ of all neonatal deaths might be avoided if breastfeeding were started on the first day of life, and $19.1 \%$ of the deaths might be avoided if breastfeeding were started within the first hour after birth [24]. Another study in Pakistan showed that almost all infants are breastfed, but that inadequate feeding practices led to poor nutrition and child mortality [25]. Exclusive breastfeeding for the first six months is the single most important factor in decreasing child morbidity and mortality [26]. Improving feeding practices will contribute to the achievement of the United Nations Millennium Development Goals. Improvements can be achieved through public awareness and health education about the importance of breastfeeding and appropriate complementary feeding in children in accordance with the Integrated Management of Neonatal Child Illness (IMNCI) Feeding Assessment Guidelines for young infant feeding [27].

Pakistan is an underdeveloped country where most of the population lives in rural areas. Mothers in these areas often have a low level of education and live in poverty, and these factors have an especially marked influence on infant and child nutrition. In addition, people in rural areas have less access to basic health care facilities. There are also misconceptions about the foods given to children, according to traditional practices without an actual scientific basis. Because of the multifactorial origin of malnutrition, appropriate intervention to reduce its incidence and prevalence in Pakistan should include: 1) education of mothers about healthy feeding practices by the Lady Health Visitors (LHV) in rural areas, 2) public awareness through mass media and community participation, and 3) the development of programs by the government and non-government organizations to provide care to malnourished children. Although great efforts are being made by WHO and the government, continued work is still needed.

\section{Conclusions}

Malnutrition in children is associated with poor breastfeeding practices. Children who were breastfed were less likely to suffer from malnutrition. More than one-third of the infants were not breastfed, mainly because of the personal preference of the mother and less amount of breast milk. These poor feeding practices can be improved by education of the mothers. The degree of malnutrition was negatively associated with age and positively associated with family 


\section{Additional Information \\ Disclosures}

Human subjects: Consent was obtained by all participants in this study. Department of Pediatric Medicine, Sargodha Medical College, DHQ Teaching Hospital, Sargodha issued approval N/A. Animal subjects: All authors have confirmed that this study did not involve animal subjects or tissue. Conflicts of interest: In compliance with the ICMJE uniform disclosure form, all authors declare the following: Payment/services info: All authors have declared that no financial support was received from any organization for the submitted work. Financial relationships: All authors have declared that they have no financial relationships at present or within the previous three years with any organizations that might have an interest in the submitted work. Other relationships: All authors have declared that there are no other relationships or activities that could appear to have influenced the submitted work.

\section{Acknowledgements}

We thank K. Shashok (AuthorAID in the Eastern Mediterranean) for improving the use of English in the manuscript.

\section{References}

1. Quantifying the health impact at national and local levels. World Health Organization Nutrition for Health and Development Protection of the Human Environment Geneva . (2005). Accessed: 27 Oct 2015: http://www.who.int/quantifying_ehimpacts/publications/MalnutritionEBD12.pdf.

2. Gopalan S: Malnutrition: Causes, consequences, and solutions. Nutrition. 2000, 16:556-58. 10.1016/S0899-9007(00)00315-4

3. Commentary: The Asian Enigma. UNICEF . (1996). Accessed: 27 Oct 2015: http://www.unicef.org/pon96/nuenigma.htm.

4. Bhutta ZA, Thaver D, Akram DS, Khan M: A situation and program analysis of malnutrition among women and children in Pakistan. Can we break the time warp?. Maternal and Child Health in Pakistan: Challenges and Opportunities. Bhutta ZA (ed): Oxford University Press, Oxford; 2004. 151-72.

5. Grantham-McGregor S: A review of studies of the effect of severe malnutrition on mental development. J Nutr. 1995, 125:2233S-2238S.

6. Bhutta ZA, Hyder AA, Ali N: Defining a new challenge for health systems: Perinatal health in Pakistan. Perinatal and newborn care in South Asia: Priorities and action 2007. Bhutta ZA (ed): Oxford University Press, Oxford; 2007. 1-30.

7. World Health Statistics. Child Mortality Estimates, CME Info, Pakistan (estimates) . (2008). Accessed: 27 Oct 2015: http://www.childmortality.org/index.php? r=site/graph \&ID=PAK_Pakistan.

8. Mujib SA, Kazmi T, Khan S, Shad MA, Bashir M, Khan B: Relationship of non-organic factors with malnutrition among children under three years of age. J Coll Physicians Surg Pak. 2006, 16:355-58.

9. Sample size calculator. (2015). Accessed: 4 December 2015: http://www.raosoft.com/samplesize.html.

10. Ali SS, Karim N, Billoo AG, Haider SS: Association of literacy of mothers with malnutrition among children under three years of age in rural area of district Malir, Karachi. J Pak Med Assoc. 2005, 55:550-53.

11. Islam MA, Rahman MM, Mahalanabis D: Maternal and socioeconomic factors and the risk of severe malnutrition in a child: a case-control study. Eur J Clin Nutr. 1994, 48:416-24.

12. Explaining Child Malnutrition in Developing Countries: A Cross-Country Analysis. International Food Policy Research Institute, Washington D.C.. (2000). Accessed: 27 Oct 2015: http://ebrary.ifpri.org/cdm/ref/collection/p15738coll2/id/48054 . 
13. Jesmin A, Yamamoto SS, Malik AA, Haque MA: Prevalence and determinants of chronic malnutrition among preschool children: a cross-sectional study in Dhaka City, Bangladesh. J Health Popul Nutr. 2011, 29:494-99. 10.3329/jhpn.v29i5.8903

14. Rayhan MI, Khan MSH: Factors causing malnutrition among under five children in Bangladesh. Pak J Nutr. 2006, 5:558-62.

15. Memon S, Shaikh S, Kousar T, Memon Y, Rubina: Assessment of infant feeding practices at a tertiary care hospital. J Pak Med Assoc. 2010, 60:1010-15.

16. Grantham-McGregor S, Cheung YB, Cueto S, Glewwe P, Richter L, Strupp B, International Child Development Steering Group: Developmental potential in the first 5 years for children in developing countries. Lancet. 2007, 369:60-70. 10.1016/S0140-6736(07)60032-4

17. Petrou S, Kupek E: Poverty and childhood undernutrition in developing countries: a multinational cohort study. Soc Sci Med. 2010, 71:1366-73. 10.1016/j.socscimed.2010.06.038

18. Cedraz LM, Carvalho FM: Family income and child malnutrition in the coast of Camaçari, Brazil (Article in Portuguese). Arch Latinoam Nutr. 1990, 40:323-32.

19. Kavosi E, Hassanzadeh Rostami Z, Kavosi Z, Nasihatkon A, Moghadami M, Heidari M: Prevalence and determinants of under-nutrition among children under six: a cross-sectional survey in Fars province, Iran. Int J Health Policy Manag. 2014, 3:71-76. 10.15171/ijhpm.2014.63

20. Nanada S: The impact of family milieu on the prevalence of protein-energy malnutrition in infants. Indian J Matern Child Health. 1996, 7:20-23.

21. Mozumder AB, Barkat-E-Khuda, Kane TT, Levin A, Ahmed S: The effect of birth interval on malnutrition in Bangladeshi infants and young children. J Biosoc Sci. 2000, 32:289-300.

22. World Health Organization: Promoting proper feeding for infants and young children. . (2011). Accessed: 27 Oct 2015: http://www.who.int/nutrition/topics/infantfeeding/en/index.html.

23. Hanif HM: Trends in breastfeeding and complementary feeding practices in Pakistan, 19902007. International Breastfeeding Journal. 2011, 6:15. 10.1186/1746-4358-6-15

24. Mullany LC, Katz J, Li YM, Khatry SK, LeClerq SC, Darmstadt GL, Tielsch JM: Breast-feeding patterns, time to initiation, and mortality risk among newborns in southern Nepal. J Nutr. 2008, 138:599-603.

25. Pakistan Demographic and Health Survey 2006-07. National Institute of Population Studies (NIPS) Islamabad Pakistan and Macro International Inc. (2007). Accessed: 27 Oct 2015: http://dhsprogram.com/pubs/pdf/FR200/FR200.pdf.

26. Toma TS, Rea MF: Benefits of breastfeeding for maternal and child health: an essay on the scientific evidence (Article in Portuguese). Cad Saude Publica. 2008, 24:S235-46. 10.1590/S0102-311X2008001400009

27. World Health Organization. Technical updates of the guidelines on integrated management of childhood illness. Department of Child and Adolescent Health and Development (CAH) 2007 19-23 Nov, Geneva, Switzerland. (2007). Accessed: 27 Oct 2015: http://apps.who.int/iris/bitstream/10665/43664/1/9789241595384_eng.pdf. 